\title{
KONSUMSI DAN POTENSI EKONOMIS RANSUM BABI LOKAL YANG DIBERI BIJI ASAM FERMENTASI
}

\author{
Redempta Wea ${ }^{1)}$, Sepriady Raidon Oematan ${ }^{2)}$, Twenfosel Ocsierly Dami Dato3), \\ dan Bernadete Barek Koten ${ }^{2)}$ \\ 1)Program Studi Produksi Ternak dan 2) Teknologi Pakan Ternak Politeknik Pertanian Negeri Kupang, \\ 3) Fakultas Peternakan Universitas Nusa Cendana, Kupang-Nusa Tenggara Timur \\ e-mail: redemptawea136@gmail.com
}

\begin{abstract}
ABSTRAK
Penelitian bertujuan mengevaluasi konsumsi dan potensi ekonomis biji asam sebagai pakan babi lokal grower telah dilaksanakan di Laboratorium Produksi Ternak Politani Negeri Kupang. Penelitian menggunakan 20 babi jantan lokal grower. Penelitian menggunakan rancangan acak kelompok dengan dua perlakuan (Ro= pakan mengandung biji asam tanpa fermentasi, R1= pakan mengandung biji asam fermentasi) dan sepuluh ulangan. Variabel penelitian adalah konsumsi ransum, income over feed cost, dan feed cost per gain. Hasil penelitian menunjukkan bahwa pakan biji asam fermentasi berpengaruh nyata $(\mathrm{P}<0,05)$ terhadap konsumsi ransum dan income over feed cost (IOFC), serta $(\mathrm{P}<0,10)$ feed cost per gain dengan nilai masing-masing yakni, o,45 dan 0,53 kg/ekor/hari, Rp.596.095,64 dan Rp. 764.310,93, serta Rp. 29.075,53/kg dan Rp. 24.250,03/kg. Kesimpulannya pakan yang mengandung biji asam fermentasi memiliki potensi ekonomis yang lebih baik dibandingkan pakan tanpa biji asam fermentasi dan disarankan agar pemerintah setempat mengambil kebijakan dalam penggunaan biji asam khususnya biji asam fermentasi sebagai pakan ternak babi.
\end{abstract}

Kata kunci: babi grower, income over feed cost, feed cost per gain

\section{CONSUMPTION AND ECONOMIC POTENTIAL OF TAMARIND SEEDS FERMENTATION AS LOCAL PIG FEED}

\begin{abstract}
The research aimed at evaluating the consumption and economic potential of tamarind seeds as local grower pig feed has been carried out in the Livestock Production Laboratory of Kupang State Agricultural Polytechnic. The study used 20 local male grower pigs. The study used a randomized block design with two treatments $(\mathrm{Ro}=$ feed containing without fermented tamarind seeds, R1 = feed containing fermented tamarind seeds) and ten replications. The research variables are the rations consumption, income over feed cost, and feed cost per gain. The results showed that fermented tamarind seed feed had a significant effect $(\mathrm{P}<0.05)$ on feed consumption and income over feed cost $(\mathrm{IOFC})$, and $(\mathrm{P}<0.10)$ feed cost per gain with their respective values ie, 0,45 and 0,53 kg/head/day, Rp.596.095,64 and Rp. 764.310,93, and Rp. 29.075,53 / $\mathrm{kg}$ and Rp. 24.250,03 / kg. In conclusion, feed containing fermented tamarind seeds has better economic potential compared to fermented sour seedless feed and it is recommended that the local government adopt a policy in the use of tamarind seeds, especially fermented tamarind seeds as pig feed.
\end{abstract}

Key words: grower pig, income over feed cost, feed cost per gain

\section{PENDAHULUAN}

Pemeliharaan ternak babi sudah membudaya di daerah Nusa Tenggara Timur (NTT) dengan dua komditi bangsa ternak babi yakni babi lokal dan babi ras. Nmaun pemeliharaan ternak babi menghabiskan biaya untuk pakan $60-80 \%$ dari keseluruhan biaya produksi serta bersaing dengan kebutuhan manusia khususnya sumber energi jagung. Oleh karena itu pakan alternatif yang diberikan oleh masyarakat NTT adalah dengan memanfaatkan biji asam.

Biji asam tanpa kulit memiliki kandungan protein kasar 13,12\%, lemak kasar 3,98\%, serat kasar 3,67\%, bahan kering $89,14 \%$, kalsium 1,2\%, phospor 0,11\%, abu 3,25\%, BETN 75,98\%, dan energi metabolis $3368 \mathrm{Kkal} / \mathrm{kg}$ (Teru, 2003). Biji asam sekalipun mengandung nutrisi yang baik namun juga memiliki kulit biji yang keras dengan lama waktu yang dibutuhkan untuk memisahkan kulit biji dan isi biji $1 \mathrm{~kg}$ biji asam \pm 2 jam sehingga sulit diolah, serta 
mengandung zat anti nutrisi tanin 2,47\% (Wea, 2019).

Keterbatasan ini dapat diatasi dengan melakukan pengolahan menggunakan teknologi fermentasi baik fermentasi spontan maupun menggunakan fermentor. Wea et al. (2013) melaporkan bahwa kandungan nutrisi biji asam yang dibiokonversi spontan selama 24 - 96 jam tidak berpengaruh terhadap bahan kering, serat kasar, dan lemak kasar, namun berpengaruh terhadap kandungan protein kasar dan energi metabolis serta rataan kandungan nutrien tertinggi terdapat pada lama fermentasi 72 jam yakni BK 90,015\%, abu 1,668\%, PK 17,663\%, SK 3,188\%, LK 6,275\%, dan EM $3340,17 \mathrm{Kkal} / \mathrm{kg}$. Namun, biji asam fermentasi tersebut belum diterapkan sebagai salah satu bahan pakan penyusun ransum bagi ternak khususnya ternak babi lokal fase grower dan bagaimana tingkat konsumsi dan potensi ekonomisnya. Tujuan penelitian adalah mengevaluasi konsumsi dan potensi ekonomis pakan yang mengandung biji asam fermentasi pada ransum ternak babi lokal grower.

\section{MATERI DAN METODE}

\section{Materi}

Materi penelitian berupa biji asam; 20 ekor babi lokal jantan grower $( \pm 3,5$ bulan) bobot badan \pm 6,14 kg; kacang tunggak (Vigna unguiculata ssp. unguiculata); vitamin mineral premix; minyak nabati (bimoli); dedak; jagung kuning; bungkil kacang kedelai (BKK) dan tepung tulang dan daging (meat and bone meal).

\section{Metode}

Penelitian ini terdiri dari dua tahap : 1). fermentasi biji asam (pengumpulan biji asam, penyangraian \pm 15 menit, pengulitan, perendaman \pm 24 jam, penirisan dan fermentasi spontan tanpa fermentor sesuai perlakuan, pengeringan $\pm 3,5$ hari, pemecahan menggunakan hammer mill, dan penggilingan menggunakan disk mill) dan 2) Perlakuan ransum (ransum diformulasi sesuai komposisi perlakuan setelah biji asam difermentasi).

Penelitian dirancang menggunakan pola rancangan acak kelompok. Perlakuan penelitian adalah : Ro = pakan mengandung biji asam tanpa fermentasi dan R1 = Pakan mengandung biji asam fermentasi dan ulangan 10 kali. Persentase penggunaan biji asam fermentasi 10\% dari total ransum 100\% (Wea et al., 2012 dan Tualaka et al., 2012). Ransum disusun sesuai kebutuhan fase grower yakni kadar air (maksimum) 14,0 \%, protein kasar 17,05, lemak kasar 3,0\%, serat kasar (maksimum) 4,5\%, abu 6,0\%, Ca o,6-1,0\%, P-total o,60\%, dan energi metabolis $3100 \mathrm{kcal} / \mathrm{kg}$ (minimal) (SNI, 2011). Komposisi ransum perlakuan seperti pada Tabel 1.
Tabel 1. Komposisi dan Kandungn Nutrien Pakan Penelitian Bahan Pakan

\begin{tabular}{lcc}
\hline & \multicolumn{2}{c}{ Komposisi Ransum (\%) } \\
\hline Jagung & Ro 1 & R1 \\
Dedak & 41 & 41 \\
MBM* & 21.5 & 22 \\
BKK $^{* *}$ & 6.5 & 6.5 \\
Kacang tunggak & 9 & 9 \\
BATF*** & 10 & 9.5 \\
Pig mix**** & 10 & 10 \\
Minyak nabati (bimoli) & 1 & 1 \\
Total & 1 & 1 \\
Kandungan nutrien : & 100 & 100 \\
BK & & \\
EM (kkal/kg) & 88,08 & 88,11 \\
PK & 3218,02 & 3211,14 \\
LK & 18,02 & 18,06 \\
SK & 6,14 & 6,23 \\
Ca & 5,61 & 5,64 \\
P & 0,74 & 0,74 \\
\hline
\end{tabular}

Ket.: Data hasil perhitungan * $\mathrm{MBM}=$ meat and bone meal; $* *$ BKK = bungkil kacang kedelai; $* * * \mathrm{BAF}=$ biji asam fermentasi : ****Vitamin mineral (premix) komersial

\section{Variabel yang diamati}

Variabel penelitian adalah:

1. Konsumsi ransum (jumlah ransum yang diberikan dikurangi sisa ransum per satuan waktu pemeliharaan)

2. Income over feed cost (IOFC) (Selisih pendapatan usaha peternakan dikurangi biaya pakan dan pendapatan merupakan perkalian antara produksi peternakan atau pertambahan bobot badan akibat perlakuan dengan harga jual (Prawirokusumo, 1990 $)$ IOFC $=($ Bobot badan akhir $\times$ harga jual $)$ - (Total konsumsi pakan $\times$ harga pakan $/ \mathrm{kg}$ )

3. Feed cost/gain, yaitu perbandingan jumlah konsumsi ransum $(\mathrm{kg} / \mathrm{ekor} / \mathrm{hr})$ dikali harga ransum $(\mathrm{Rp} / \mathrm{kg})$ dengan pertambahan bobot badan (kg/ekor/hr).

\section{Analisis Data}

Data dianalisis dengan analisis ragam (ANOVA) menggunakan uji T (Gazpersz, 1991).

\section{HASIL DAN PEMBAHASAN}

Usaha pemeliharaan ternak babi agar dapat menguntungkan maka perlu diketahui potensi ekonomisnya. Potensi ekonomis ransum yang digunakan dapat diketahui dengan mengukur tingkat konsumsi ransum, income over feed cost dan feed cos per gain disamping itu juga harus mengetahui harga ransum per kg yang diformulasi agar diketahui total biaya konsumsi ransum yang dikeluarkan. Konsumsi dan potensi ekonomis ransum yang mengandung biji asam fermentasi dan yang tidak, disajikan pada Tabel 1. 
Tabel 1. Konsumsi dan potensi ekonomis ransum perlakuan

\begin{tabular}{lcc}
\hline \multirow{2}{*}{\multicolumn{1}{c}{ Variabel }} & \multicolumn{2}{c}{ Perlakuan } \\
\cline { 2 - 3 } & Ro & R1 \\
\hline Konsumsi ransum (kg/ekor/hari) & $0,45^{\mathrm{b}}$ & $0,53^{\mathrm{a}}$ \\
Pertambahan bobot badan & $0,09^{\mathrm{b}}$ & $0,12^{\mathrm{a}}$ \\
Harga pakan (Rp/kg) & $5490^{\mathrm{a}}$ & $547 \mathrm{0}^{\mathrm{b}}$ \\
Total biaya konsumsi ransum & $123904,359^{\mathrm{b}}$ & $145689,074^{\mathrm{a}}$ \\
(Rp/ekor/5ohari) & & \\
Feed cost per gain (Rp/kg) & $29.075,53^{\mathrm{a}}$ & $24.250,03^{\mathrm{b}}$ \\
Income over feed cost (Rp/ekor) & $596.095,64^{\mathrm{b}}$ & $764.310,93^{\mathrm{a}}$
\end{tabular}

Keterangan : ${ }^{a, b}=$ Rataan dengan superskrip yang sama menunjukkan tidak berbeda nyata $(P>0,05)$ dan superskrip berbeda pada baris yang sama menunjukkan perbedaan nyata $(P<0,10)$

\section{Konsumsi Ransum}

Berdasarkan data pada Tabel 1 terlihat bahwa penggunaan biji asam fermentasi dalam ransum berpengaruh nyata $(\mathrm{P}<0,05)$ terhadap konsumsi ransum ternak babi lokal grower yaitu $0,53 \mathrm{~kg} / \mathrm{ekor} /$ hari, $17,78 \%$ lebih tinggi dibandingkan konsumsi ransum babi yang mendapatkan biji asam tanpa terfermentasi. Hal ini menunjukkan bahwa pemberian pakan yang mengandung bji asam fermentasi memiliki tingkat palatabilitas yang lebih baik dibanding pakan yang mengandung biji asam tanpa fermentasi.

Hal ini dapat dijelaskan bahwa teknologi fermentasi yang dilakukan pada biji asam mampu menyediakan nutrien yang lebih baik sehingga dapat dikonsumsi oleh ternak dan berguna bagi pertumbuhannya. Fermentasi yang terjadi melibatkan reaksi enzim yang dihasilkan oleh mikroorganisme dan mampu mengubah fisik dan kimia bahan organik kompleks menjadi sederhana (Riadi, 2007).

Konsumsi ransum ternak babi khususnya yang mengkonsumsi biji asam fermentasi spontan pada penelitian ini lebih tinggi $(0,53 \mathrm{~kg} /$ ekor/hari) dibanding konsumsi ransum babi lokal grower yang mengonsumsi fermentasi biji asam yang menggunakan ragi tempe (Wea, 2013) yakni 348,39 g/ekor/hari namun, pertambahan bobot badan (PBB) yang dihasilkan penelitian ini lebih rendah (0,12 kg/ekor/ hari) dibanding PBB ternak babi lokal jantan grower yang mengonsumsi biji asam fermentasi ragi tempe yakni 123,67 g/ekor/hari. Perbedaan ini disebabkan karena adanya perbedaan pada kondisi lingkungan penelitian yakni penelitian ini dilaksanakan pada awal musim hujan (bulan November) sedangkan penelitian Wea (2013) dilakukan pada bulan Mei, kualitas bahan pakan yang digunakan, serta cara pengolahan yang dilakukan.

\section{Income Over Feed Cost (IOFC)}

Income over feed cost (IOFC) merupakan selisih total pendapatan (PBB dan harga jual) dengan total biaya pakan yang digunakan selama usaha penggemukan. Mayulu (2009) menyatakan bahwa IOFC merupakan selisih antara penerimaan dengan biaya pakan.

Berdasarkan data pada Tabel 1 terlihat bahwa rataan IOFC berbeda nyata $(\mathrm{P}<0,05)$ antara kedua perlakuan dimana rataan tertinggi terdapat pada perlakuan biji asam yang difermentasi (R1) yaitu sebesar Rp.764.310,93/ekor sedangkan perlakuan tanpa fermentasi (Ro) sebesar Rp.569.095,64/ekor. Hal ini menunjukkan bahwa pakan yang mengandung fermentasi biji asam lebih baik dibandingkan tanpa fermentasi. Dinyatakan demikian karena semakin tingi nilai IOFC maka akan semakin baik pula pemeliharaan yang dilakukan. Perhitungan IOFC dilakukan untuk mengetahui nilai ekonomis pakan terhadap pendapatan peternak. Income over feed cost (IOFC) dilakukan karena biaya pakan berkisar antara $60-80 \%$ dari biaya total produksi.

Hasil analisis ragam menunjukkan bahwa IOFC pada perlakuan ransum yang mengandung biji asam tanpa fermentasi (Ro) dan perlakuan ransum yang mengandung biji asam fermentasi (R1) memberikan perbedaan nyata $(\mathrm{P}<0,05)$ terhadap IOFC ternak babi jantan lokal fase grower. Hal ini menunjukkan bahwa penerimaan terbesar dari biaya pakan yang dikeluarkan dengan penjualan ternak babi adalah pada ternak babi yang mengonsumsi fermentasi biji asam selama 72 jam dalam ransum.

Rasyaf (2011) menyatakan bahwa semakin tinggi nilai IOFC akan semakin baik pula pemeliharaan yang dilakukan. Hal ini dikarenakan tingginya IOFC berarti penerimaan yang didapat dari hasil ternak babi juga semakin tinggi. Perbedaan tersebut dikarenakan oleh konsumsi pakan, harga pakan yang berbeda dari setiap perlakuan, dan PBB ternak juga berpengaruh terhadap IOFC.

Rataan IOFC pada penelitian ini lebih tinggi dibandingkan hasil penelitian Idris (2013), yang melaporkan bahwa IOFC terbaik terdapat pada level o\% penambahan POD kakao fermentasi dalam ransum ternak babi sebesar Rp. 399.976,60/ekor. Kondisi ini terjadi karena biaya pakan yang dikeluarkan serta jumlah pakan yang dikonsumsi yang berpengaruh pada harga pakan yang harus dikeluarkan selama masa penelitian. Hal ini didukung oleh pendapat Prawirokusumo (1990) yang menyatakan bahwa IOFC adalah selisih antara pendapatan usaha peternakan terhadapa biaya pakan. Pendapatan ini merupakan perkalian antara produksi peternakan dengan harga jual, sedangkan biaya pakan adalah jumlah biaya yang dikeluarkan untuk menghasilkan ternak tersebut.

Demikian juga pernyataan De Jong et al. (2012) yang menyatakan bahwa IOFC merupakn selisih antara total pendapatn dengan biaya pakan. Pendapatan merupakan perkalian antara hasil produksi peternakan (kilogram hidup) dengan harga jual, sedangkan biaya pakan adalah jumlah biaya 
pakan yang dikeluarkan menghasilkan kilogram bobot hidup.

\section{Pengaruh Perlakuan terhadap Feed Cost per Gain (FCG)}

Feed cost per gain (FCG) diartikan sebagai jumlah biaya pakan yang dibutuhkan untuk setiap kenaikan $1 \mathrm{~kg}$ berat badan ternak. Feed cost per gain dihitung dengan cara jumlah konsumsi ransum (kg/ekor/ hari) dikali harga ransum $(\mathrm{Rp} / \mathrm{kg})$ dibagi dengan pertambahan bobot badan (kg/ekor/hari). Feed cost per gain (FCG) ternak babi yang mengonsumsi biji asam fermentasi dalam ransum disajikan pada Tabel 1.

Hasil analisis statistik menunjukkan bahwa ratarata feed cost per gain pada perlakuan biji asam fermentasi (R1) lebih efisien daripada perlakuan biji asam tanpa fermentasi (Ro) karena ternak babi yang mengonsumsi pakan yang mengandung fermentasi biji asam hanya membutuhkan biaya pakan sebesar Rp. 24.250,03 untuk menghasilkan $1 \mathrm{~kg}$ bobot badan dibandingkan dengan ternak babi yang mengonsumsi pakan yang mengandung biji asam tanpa fermentasi harus membutuhkan biaya sebesar Rp. 29.075,53 untuk menghasilkan $1 \mathrm{~kg}$ bobot badan atau lebih besar biaya yang dibutuhkan.

Hasil analisis ragam menunjukkan bahwa terdapat perbedaan yang sangat nyata $(\mathrm{P}<0,10)$ antara perlakuan biji asam tanpa fermentasi (Ro) dengan perlakuan biji asam fermentasi (R1). Perbedaan ini disebabkan karena faktor konsumsi pakan (o,45 dan 0,53 kg/ekor/hari), harga pakan (Rp. 5490/kg dan Rp.5470/kg) dan pertambahan bobot badan (0,09 $\mathrm{kg} /$ ekor/hari dan $0,12 \mathrm{~kg} /$ ekor/hari) yang berbeda pada setiap perlakuan.

Terlihat bahwa faktor utama yang mempengaruhi feed cost per gain pada perlakuan biji asam tanpa fermentasi (Ro) adalah karena harga pakan yang tinggi. Meningkatnya biaya pakan belum tentu pakan tersebut dikonsumsi ternak sesuai dengan yang diharapkan, sehingga berpengaruh terhadap pertambahan bobot badan (PBB) yang dihasilkan sehingga akan berdampak pada biaya yang dikeluarkan menjadi meningkat. Hal ini sesuai pernyataan Basuki (2000) bahwa untuk mendapatkan feed cost per gain rendah maka pemilihan bahan pakan penyusun ransum harus semurah mungkin dan tersedia secara kontinyu atau dapat juga menggunakan limbah pertanian yang tidak kompetitif. Feed cost per gain dapat ditekan dengan memilih bahan pakan untuk menyusun ransum yang mudah dicari atau tersedia secara kontinyu dan murah harganya akan tetapi dapat saling melengkapi membentuk formasi yang serasi dan seimbang. Hal senada dinyatakan oleh Sugiharto (2004) bahwa nilai feed cost per gain erat kaitannya dengan menurunnya nilai konversi pakan. Semakin rendah nilai konversi pakan maka semakin rendah biaya yang harus dikeluarkan untuk pertambahan bobot badan.

Berdasarkan hasil penelitian menunjukkan bahwa nilai rataan feed cost per gain terbaik ternak babi lokal yang mengonsumsi fermentasi biji asam yaitu sebesar Rp. 24.250,03 untuk menghasilkan $1 \mathrm{~kg}$ bobot badan sangat berbeda jauh atau tidak terlalu ekonomis dibandingkan dengan hasil penelitian Budaarsa (2015) yaitu pemanfaatan ampas tahu fermentasi untuk mengganti ransum komersial ternak babi yang hanya membutukan biaya sebesar Rp.11.878 untuk menghasilkan $1 \mathrm{~kg}$ bobot badan. Besar kecilnya feed cost per gain dipengaruhi oleh konversi pakan dan biaya pakan. Hal ini sesuai pernyataan Kojo et al. (2014) bahwa biaya produksi harus diperhitungkan dalam suatu usaha peternakan babi karena biaya produksi berhubungan dengan jumlah yang akan diproduksi Ada 3 komponen untuk menghitung feed cost per gain, yaitu; harga pakan yang digunakan untuk menyusun ransum, jumlah bahan pakan yang dikonsumsi setiap harinya, serta rerata pertambahan bobot badan yang dihasilkan.

\section{SIMPULAN DAN SARAN}

Pemanfaatan biji asam fermentasi dalam ransum memberikan nilai ekonomis terhadap babi lokal grower dengan income over feed cost dan feed cost per gain yang lebih baik dibanding tanpa fermentasi.

Pemerintah setempat mengambil kebijakan tentang pemanfaatan biji asam fermentasi sebagai sumber bahan pakan lokal potensial dengan mendirikan wadah yang dapat menampung limbah biji asam dari masyarakat.

\section{DAFTAR PUSTAKA}

Basuki. P. 2000. Pengantar ilmu ternak potong dan kerja. Bahan kuliah. Yogyakarta: Fakultas Peternakan Universitas Gadjah Mada

Budaarsa. 2015. Pengaruh penggantian ransum komersial terhadap kecernaan pakan pada babi ras. Majalah Ilmiah Peternakan.18.1: 22-25.

De Jong, A., J. M. DeRouchey, M. D. Tokach, R. D. Goodband, S. S. Dritz, J. L. Nelssen, and L. McKinney. 2012. Effects of Corn Particle Size, Complete Diet Grinding, and Diet Form on Finishing Pig Growth Performance, Caloric Efficiency, Carcass Characteristics, and Economics. Conference: Swine Day, Manhattan, KS, November 15, 2012. p. 316-324. https://krex.k-state.edu/ dspace/bitstream/handle/2097/15137/29\%20 Corn \% 2 o Particle\% 2 o Size\% 2 c\% 20 Complete\%2oDiet\%2oGrinding\%2opg316-324. 
pdf? sequence $=1$ \&isAllowed $=\mathrm{y}$

Gaspersz, V. 1991. Metode perancangan percobaan. CV. ARMICO. Bandung.

Idris Kristian. 2013. Analisis usaha pemanfaatan pod kakao (Theobroma cacao L.) difermentasi rhizopus sp, saccharomyces sp dan lactobacillus $s p$ terhadap ternak babi jantan peranakan Landrace. Program Studi Peternakan Fakultas Pertanian Universitas Sumatera Utara. 2013

Kojo R. E., V. V. J. Panelewen, M. A.V. Manese, dan N. Santa., 2014. Efisiensi penggunaan input pakan dan keuntungan pada usaha ternak babi di Kecamatan Tareran Kabupaten Minahasa Selatan. Jurnal Zootek. Vol. 34 (1) : 62-74.

Mayulu, H., B. Suryanto, S. Sunarso, M. Christiyanto, F. Ballo and R. Refa'i. 2009. Feasibility of complete feed based on ammonitiated fermented rice straw utilization on the beef cattle farming. J. I. Tropic. Anim. Agri. 34: 74-78.

Prawirokusumo, S. 1990. Ilmu usaha tani. BPFE. Yogyakarta

Rasyaf, M. 2011. Panduan beternak ayam petelur. Edisi ke XV Kanisisus : Yogyakarta

Riadi, Lieke. 2007. Teknologi fermentasi. Graha Ilmu. Yogyakarta.

Sihombing, Luhut. 2010. Tata niaga hasil pertanian. Medan. USU Press.

SNI. 2011. Pakan Ternak Babi (grower). Standar Nasional Indonesia (SNI) pakan ternak dan bahan baku peternakan. Badan Standarisasi Nasional.

Sugiharto, R. S. 2004. Meningkatkan keuntungan dalam usaha peternakan. Agromedia Pustaka, Jakarta.
Teru V. Y., 2003. Pengaruh subtitusi jagung dengan tepung biji asam tanpa kulit terhadap bobot hidup, bobot karkas, dan presentase karkas broiler fase finisher. Skripsi Fakultas Peternakan Undana Kupang.

Tualaka, Y. F., R. Wea, dan T. N. Koni., 2012. Pemanfaatan biji asam fermentasi dengan ragi tempe (rhyzopus oligosporus) terhadap kecernaan bahan kering dan protein ransum ternak babi lokal jantan. Jurnal Partner, Buletin Pertanian Terapan Politani Negeri Kupang. Tahun 19, No. 2: 152-164

Wea, R., T. N. Koni, , B. B. Koten., 2012. Identifikasi komposisi tubuh dan performans produksi babi lokal jantan yang mengonsumsi ransum olahan biji asam dalam ransum. Laporan Penelitian Hibah Fundamental. Politeknik Pertanian Negeri Kupang.

Wea, R. 2013. Performans pertumbuhan babi lokal jantan yang mengonsumsi pakan olahan biji asam dalm ransum. Jurnal Partner. Tahun 20 (2): 133-143

Wea, R., B. B. Koten, T. N. I. Koni., 2013. Identifikasi komposisi tubuh babi timor jantan yang dipelihara secara ekstensif. Jurnal veteriner peternakan. Vol. 14 No. 3: 358-364. Politeknik pertanian negeri kupang.

Wea, R. 2019. Fermentasi biji asam dengan karbohidrat mudah larut asal nira lontar terhadap kinerja produksi dan kualitas daging babi persilangan. Disertasi Pasca Sarjana Universitas Nusa Cendana.Allden. W. G. and I. A. McD. Whittaker. 1970. The determinants of herbage intake by grazing sheep. Aust. J. Agric. Res. 21: 755-66. 